\title{
Sustainable alkali-activated binders with municipal solid waste incineration ashes as sand or fly ash replacement
}

\author{
Mohammad R. Irshidat $^{1}$ D $\cdot$ Nasser Al-Nuaimi ${ }^{1} \cdot$ Mohamed Rabie $^{1}$
}

Received: 14 September 2021 / Accepted: 15 February 2022 / Published online: 2 March 2022

(c) The Author(s) 2022

\begin{abstract}
The present study investigates the feasibility of using two types of municipality solid wastes incineration ashes, namely, fly ash and bottom ash in the production of sustainable alkali-activated binder. The ashes are collected from the incineration plant and characterized to determine their particle size distribution, specific gravity, chemical composition, and heavy metals content. The ashes are then used as either fly ash or sand replacement with five replacement ratios $0 \%, 5 \%, 10 \%, 15 \%$, and $20 \%$ to produce the binder. The produced binder are characterized in terms of strength, workability, density, water absorption, thermal conductivity and stability, chemical composition, and heavy metals content. The results reflect the ability of producing sustainable alkali-activated binder with small dosage of MSWI ashes as either fly ash or sand replacement without negatively affecting its strength, workability, density, and water absorption. The ashes enhance the thermal insulation capability of the binder.
\end{abstract}

Keywords Municipal solid waste $\cdot$ Incineration ashes $\cdot$ Alkali-activated binder $\cdot$ Mechanical properties $\cdot$ Thermal characteristics · Heavy metals

\section{Introduction}

Rapid urbanization and social civilization have accelerated the generation of municipal solid wastes (MSW) all over the world. In 2016, two billion tons of MSW were generated around the world, this number is expected to greatly increase in the future [1]. It has been reported that the annual generation of the MSW in the United States, Europe, China, and India are 238.5, 241, 300, and 238 million tons [2, 3], respectively. The huge generation of the MSW draws the attention of the municipalities and nations toward this troubling issue as it can cause serious problems to the human health and environment. Accordingly, an effective way to recycle these wastes become necessary all over the world. The traditional treatment solutions of the MSW include recycling, landfilling, or incineration [3-5]. Among the

Mohammad R. Irshidat on leave from Jordan University of Science and Technology (JUST), Jordan.

Mohammad R. Irshidat

mirshidat@qu.edu.qa

1 Center for Advanced Materials (CAM), Qatar University, P.O. Box 2713, Doha, Qatar aforementioned solutions, landfilling is the conventional technique that globally used to deal with these wastes. However, landfilling MSW owns many drawbacks, such as possible contaminating water and soil, greenhouse gas emission, and limited available spaces for landfill in most countries [4]. These drawbacks and the environmental awareness encourage the nations to look for more practical and sustainable techniques to get rid of these wastes. In this regard, incineration represents a more promising technique to implement. Incineration of MSW not only reduces the volume of the wastes by $90 \%$ [6] and kills the viruses and bacteria at such high temperatures [7], but also allows producing energy from waste. The waste-to-energy principle led to change the traditional concept of considering wastes as pollution towards treatment of the wastes as resources [3].

Despite of the above-mentioned benefits of MSW incineration, it produces considerable amount of solid residues, mainly bottom (BA) ash and fly ash (FA). Unfortunately, the heavy metals contained in the wastes migrate into the ashes. Due to the significant presence of these toxic chemicals, many countries consider the municipal solid waste incineration (MSWI) ashes, especially the FA, as hazardous materials [8]. Thus, further treatment of these wastes are highly required. Many treatment techniques of the MSWI 
ashes have been utilized including underground storage or landfilling, thermal and chemical treatments. Among the aforementioned techniques, landfilling is the simplest one. However, this technique requires a large space of land [9], and faces the regulations and policies of many countries due to the potential health and environmental concerns [5]. On the other hand, thermal and chemical treatments have been employed to extract the heavy metals from the MSWI ashes. Despite the efficiency of these two techniques, many concerns have been reported in the literature such as the extra energy consumption required by the thermal treatment and the long-term stability issue of the chemical treated ashes [5].

Recently, solidification or immobilization of the heavy metals by incorporating them in the production of alkaliactivated (geopolymer) composites were successfully employed as new treatment techniques. During the geopolymerization process, reaction products with $3 \mathrm{D}$ network are formulated with the ability of encapsulating the heavy metals inside the matrix [10]. Thus, incorporating MSWI ashes in geopolymer composites production has started to catch research interest. The MSWI ashes were utilized in the preparation of the alkali-activated binders as either partially replacement of the source materials [11] or as the only source material [12]. Diaz-Loya et al. and Ye et al. [13, 14] reported that even though using MSWI FA to replace the source materials decreased the mechanical strengths of the geopolymer, the products met the acceptance criteria for the waste landfilling. Other studies showed that geopolymer with good mechanical properties could be produced even with incorporating the MSWI FA as source materials [15, 16]. Wongsa et al. [17] investigated the effect of partially substitution of source materials with MSWIBA on the strength of fly ash-based geopolymer composites. Their results showed that up to $40 \%$ of the fly ash content could be replaced by MSWIBA without negatively affecting the compressive strength of the geopolymer. Ren et al. [18] showed that using silica fume and sodium silicates enhanced the compressive strength of geopolymer composites made by MSWIFA as source materials. In addition to the acceptable mechanical properties of the geopolymer composites made of MSWI ashes as the sole or partial source materials, they also benefits the solidification of heavy metals [5, 17-19].

As the alkali-activated (geopolymer) materials showed excellent potential to serve as heavy metals immobilizing agent, most of the studies focused on investigating the ability of these composites to stabilize these hazardous materials. Little focus has been given to investigate the mechanical properties of the produced geopolymers [3, 4]. Moreover, the MSWI ashes have been mainly used as source materials and the attention was paid to investigate the effect of the synthesis parameters on the heavy metal solidification and stabilization efficiency. The current research focuses on investigating the ability of using MSWI ashes in geopolymer composites production not only as source materials replacement but also as sand replacement. The novelty of this work comes from two points: (1) little or no studies used the MSWI ashes as sand replacement in geopolymer composites, (2) little studies focused on investigating the fresh and harden properties of alkali activated binders made of MSWI ashes. In this study, MSWI bottom ash and fly ash were used as either sand replacement or fly ash replacement in alkali-activated binder production. The effect of the replacement ratio on the mechanical strengths, workability, density, water absorption, thermal insulation capacity, thermal stability, and chemical composition of the fly ash-based geopolymer composites were explored.

\section{Experimental program}

\section{Characterization of MSWI ashes}

Two MSWI ashes include fly ash and bottom ash were used in this study as received from the incineration plant at the Domestic Solid Waste Management Center (DSWMC) in Qatar. Comprehensive experiments were conducted to characterize these ashes before implemented into the geopolymer mix. The particle size distribution (PSD), particles' shape, specific gravity, chemical composition, and the total concentration of heavy metals of the MSWIFA and MSWIBA were investigated. The PSD is plotted in Fig. 1. It is clear in the figure that the MSWIFA owned finer particles and narrow and less varied PSD than MSWIBA. The size of the MSWIBA particles was close to the size of the silica sand particles used in preparing the alkali-activated binder. The D50 of the silica sand, MSWIBA, and MSWIFA were equal to $550 \mu \mathrm{m}, 500 \mu \mathrm{m}$, and $130 \mu \mathrm{m}$, respectively. According to the scanning electron microscopic (SEM) imaging

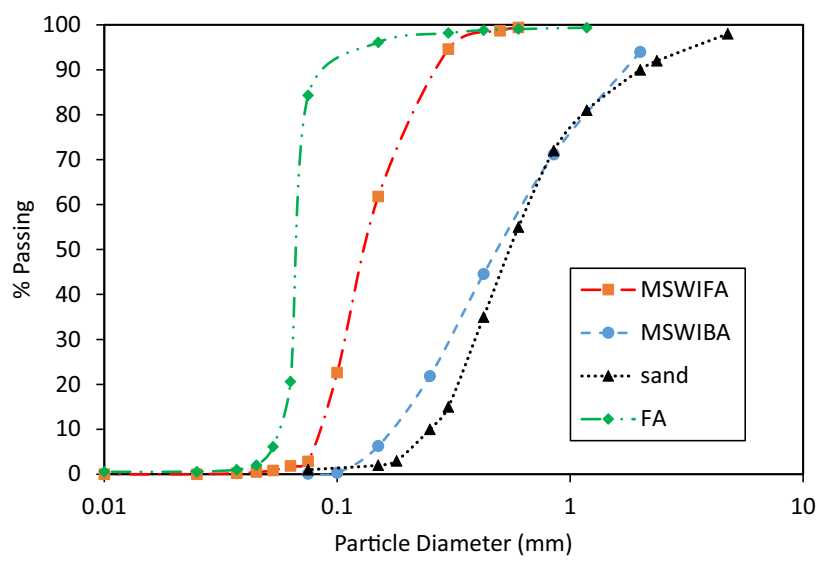

Fig. 1 Particle size distribution of fly ash, sand, and MSWI ashes 
Fig. 2 SEM imaging of a MWSIBA and $\mathbf{b}$ MSWIFA
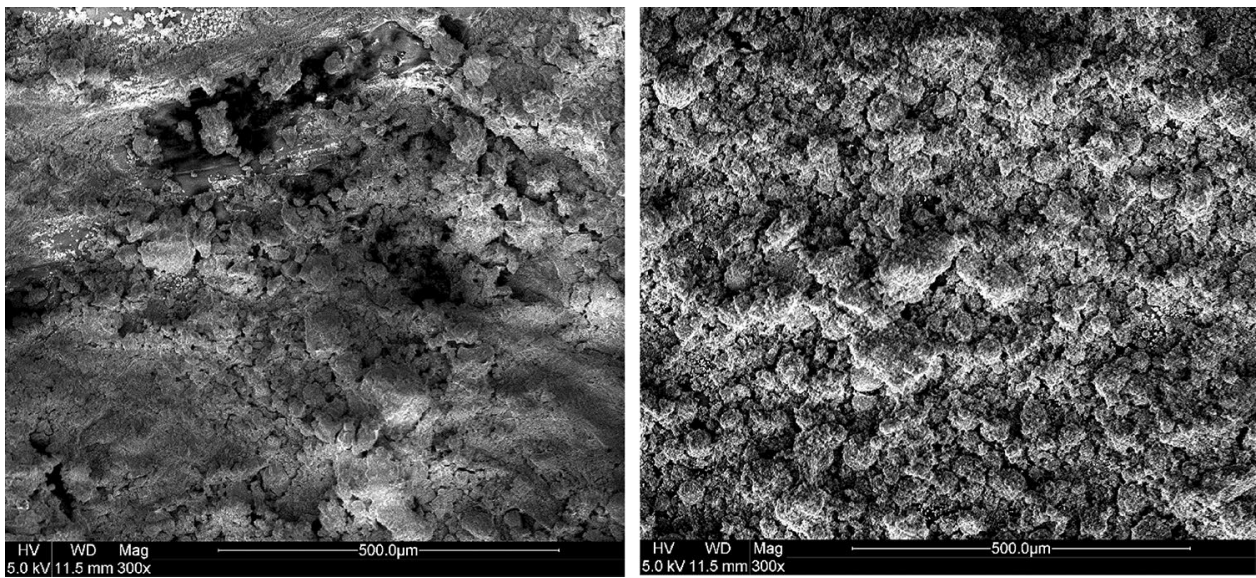

Table 1 Chemical composition of ashes used in this study

\begin{tabular}{llll}
\hline Oxides & MSWIBA (\%) & MSWIFA (\%) & Fly ash (\%) \\
\hline $\mathrm{CaO}$ & 46.8 & 61.8 & 11.80 \\
$\mathrm{Fe}_{2} \mathrm{O}_{3}$ & 20 & 2.4 & 7.83 \\
$\mathrm{SiO}_{2}$ & 9.6 & 6.6 & 49.90 \\
$\mathrm{Al}_{2} \mathrm{O}_{3}$ & 5.1 & 1.2 & 17.10 \\
$\mathrm{Na}_{2} \mathrm{O}$ & 4.1 & - & 0.14 \\
$\mathrm{SO}_{3}$ & 3.7 & 12.1 & 0.42 \\
$\mathrm{MgO}$ & 2.5 & 3.4 & 4.90 \\
$\mathrm{~K}_{2} \mathrm{O}$ & 0.1 & 4 & 0.28 \\
$\mathrm{ZnO}$ & 2 & 3.3 & - \\
$\mathrm{P}_{2} \mathrm{O}_{5}$ & 1.9 & 1.4 & - \\
$\mathrm{CuO}$ & 1.1 & 0.4 & - \\
$\mathrm{PbO}$ & 0.8 & 1 & - \\
$\mathrm{TiO}_{2}$ & 0.7 & 0.1 & - \\
$\mathrm{BaO}$ & 0.4 & 0.5 & - \\
$\mathrm{SnO}_{2}$ & 0.2 & 0.5 & - \\
$\mathrm{Sb}_{2} \mathrm{O}_{3}$ & 0.2 & 0.5 & - \\
$\mathrm{MnO}_{\mathrm{ZnO}}$ & 0.1 & - & - \\
$\mathrm{ZrO}_{2}$ & 0.1 & - & - \\
$\mathrm{CdO}$ & - & 0.2 & - \\
$\mathrm{Ta}_{2} \mathrm{O}_{5}$ & - & 0.1 & - \\
$\mathrm{Cr}_{2} \mathrm{O}_{3}$ & - & 0.1 & - \\
$\mathrm{As}_{2} \mathrm{O}_{3}$ & - & 0.1 & - \\
\hline & & & -
\end{tabular}

(Fig. 2), both MSWIBA and MSWIFA have irregular non spherical shapes. The SEM analysis was conducted using NOVA NanoSEM 450 device. The specific gravity of the MSWIFA and MSWIBA were found to be 2.25 and 2.07, respectively. X-ray fluorescence (XRF) test procedure was conducted using JSX 3201 M (Jeol) spectroscopy machine to determine the chemical composition of the MSWI ashes. The results are summarized in Table 1. It clear that both ashes have high calcium oxide $(\mathrm{CaO})$ content. Compared to MSWIFA, MSWIBA shows higher contents of alumina, silica, and iron oxide, but a lower content of sulfur trioxide $\left(\mathrm{SO}_{3}\right)$. In addition, some alkali metals, such as sodium and magnesium oxides, and heavy metals such as zinc and lead were detected in both ashes. The presence of heavy metals in the ashes encouraged to conduct ICP-OES analysis to investigate the total concentration of these metals. The traced elements include $\mathrm{Cu}, \mathrm{Cr}, \mathrm{Mn}, \mathrm{Ni}, \mathrm{Zn}$, and $\mathrm{Pb}$. The results are presented in Table 2 . The amount of heavy metals found in MSWIBA was much higher than that of MSWIFA. Compared to the values reported in the literatures [20, 21], the amount of $\mathrm{Zn}$ and $\mathrm{Cr}$ founded in MSWIBA were below the minimum values, whereas the amount of $\mathrm{Ni}$ and $\mathrm{Pb}$ were closer to the minimum reported values than they were to the maximum. In the case of MSWIFA, the amount of $\mathrm{Cr}$, $\mathrm{Ni}$, and $\mathrm{Zn}$ were found to be below the minimum values reported in the literature, whereas the amount of $\mathrm{Cu}$ and $\mathrm{Pb}$ were closer to the minimum reported values than they were to the maximum.
Table 2 Heavy metals concentrations in the incineration ashes

\begin{tabular}{lllllll}
\hline Sample ID & \multicolumn{6}{l}{ Concentration $(\mu \mathrm{g} / \mathrm{g})$} \\
\cline { 2 - 7 } & $\mathrm{Cu}$ & $\mathrm{Cr}$ & $\mathrm{Mn}$ & $\mathrm{Ni}$ & $\mathrm{Zn}$ & $\mathrm{Pb}$ \\
\hline MSWIFA & 378 & 30 & 97 & 11 & 2397 & 813 \\
MSWIBA & 5341 & 115 & 426 & 27 & 1288 & 1642 \\
$(\text { Min-max })^{\mathrm{a}}$ & $330-5530$ & $120-2026$ & $\mathrm{NA}$ & $17-614$ & $3800-16,800$ & $640-5500$ \\
\hline
\end{tabular}

${ }^{\mathrm{a}}$ Funari et al. [20] 


\section{Materials}

The alkali-activated binder was prepared with class $\mathrm{F}$ fly ash, silica sand, Sodium Hydroxide $(\mathrm{NaOH})$ and Sodium Silicate $\left(\mathrm{Na}_{2} \mathrm{SiO}_{3}\right)$. In addition, (PC 485, EPSILONE) superplasticizer was used to enhance the workability of the mix. The fly ash was received from SMEET Qatar, and characterized in terms of particle size distribution, chemical composition, moisture content, and density. Figure 1 shows that the fly ash owned finer particles and narrow and less varied PSD than the MSWI ashes. The chemical composition of the fly ash is complying with ASTM C618-12a standards, as shown in Table 1 . The density and the moisture content of the fly ash were equal to $2.23 \mathrm{~g} / \mathrm{cm}^{3}$ and $0.5 \%$, respectively. Locally available silica sand with specific gravity, fineness modulus, and water absorption of $2.56,2.31$, and $1.87 \%$, respectively, was used. The sand conforms to ASTM C778 standard. The Sodium Silicate solution was received from Qatar Detergent Company in Qatar with $\mathrm{Na}_{2} \mathrm{SiO}_{3}$ concentration of $40 \%$. The $\mathrm{NaOH}$ solution was prepared using $\mathrm{NaOH}$ pellets with purity of $98 \%$ that was acquired from a local supplier. The $\mathrm{NaOH}$ solution with concentrations of 10 Molar was prepared by mixing $320 \mathrm{~g}$ of $\mathrm{NaOH}$ pellets in one liter of distilled water. Since the reaction between the $\mathrm{NaOH}$ and water is exothermic reaction, the solution was prepared in a big plastic container immersed in a water bath to accommodate the heat of the reaction. The solution was left at room temperature for 30 min to lower its temperature, and was then poured in an airtight glass jar to prevent the reaction with air.

\section{Mix design and alkali-activated binder preparation}

The MSWI ashes were incorporated into the mixes as either fly ash replacement or sand replacement. For each approach, four different replacement ratios were used: $5 \%, 10 \%, 15 \%$, and $20 \%$ by weight of fly ash or sand. The purpose of the replacement was to investigate the amount of the MSWI ashes that could be incorporated into the mixes without negatively affecting the mechanical and physical properties of the binders. Twenty different mixes were used to prepare the alkali-activated binders, as shown in Table 3. All mixes were prepared with $\mathrm{NaOH}$ solution with ten molarity $(10 \mathrm{M})$, fluid to binder ratio of one, and Sodium Silicates to Sodium Hydroxide ratio of 2.0. The specimens were designated by BA or FA, which refer to the type of the incineration ash, followed by letters $\mathrm{S}$ or $\mathrm{F}$, which refers to sand or fly ash, and followed by number refers to the replacement ratio.

The alkali-activated binder was prepared by mixing the $\mathrm{NaOH}$ and $\mathrm{Na}_{2} \mathrm{SiO}_{3}$ solutions for 2 min in a glass-measuring jar. The MSWI ashes were dry mixed with either sand or fly ash. The activator solutions were placed in the mixing bowl, and fly ash (with or without MSWI ashes) were added and mixed in the mixing bowl for $30 \mathrm{~s}$ at low speed. After that, the sand (with or without MSWI ashes) was added to the mix and mixes for $30 \mathrm{~s}$ at low speed. The mixing speed increased to high speed and the mixing continues for $120 \mathrm{~s}$. At this point, the flow table test was conducted, followed by $15 \mathrm{~s}$ mixing at high speed. The prepared binder was used to cast specimens with dimensions of $5 \mathrm{~cm} \times 5 \mathrm{~cm} \times 5 \mathrm{~cm}$ and $4 \mathrm{~cm} \times 4 \mathrm{~cm} \times 16 \mathrm{~cm}$ to perform the compressive and flexural strength tests, respectively. All geopolymer mortar specimens were cured at a fixed temperature of $80{ }^{\circ} \mathrm{C}$ and for a duration of $24 \mathrm{~h}$. After curing, the specimens were tested according to the procedures mentioned in the following section.

\section{Test procedures}

\section{Mechanical strengths}

The mechanical behavior of alkali-activated binder with MSWI ashes was investigated through compressive and flexural strength tests according to the ASTM C109 and ASTM C348 standards, respectively. The specimens were loaded until failure with loading rate of $1.3 \mathrm{kN} / \mathrm{s}$ and $0.044 \mathrm{kN} / \mathrm{s}$ for compression and flexural tests, respectively. The average strength value of three tested specimens for each mix was reported.

\section{Workability}

Effect of MSWI ashes on the workability of the alkali-activated binder was investigated using flow table test according to the ASTM C1437 standards. The average of four readings for each mix was calculated and reported.

\section{Density}

The effect of MSWI ashes on the density of the produced binder was determined according to the following procedure: three $50 \mathrm{~mm}$ cubes for each mix design were placed in an oven for $24 \mathrm{~h}$ at $110^{\circ} \mathrm{C}$. The specimens were removed from the oven and cool in an ambient temperature for $2 \mathrm{~h}$, and the dry weight was recorded for all specimens. The oven dry density was calculated by dividing the oven dry weight by the volume of specimen. The average of three density values of each mix were reported.

\section{Thermal conductivity}

Thermal conductivity of alkali-activated binder with various dosages of MSWI ashes as either fly ash replacement or sand replacement was examined using a hot disk thermal constant analyzer machine. The sensor of the machine was sandwiched between two-binder specimens, and then the transient plane source (TPS) method was used to acquire 


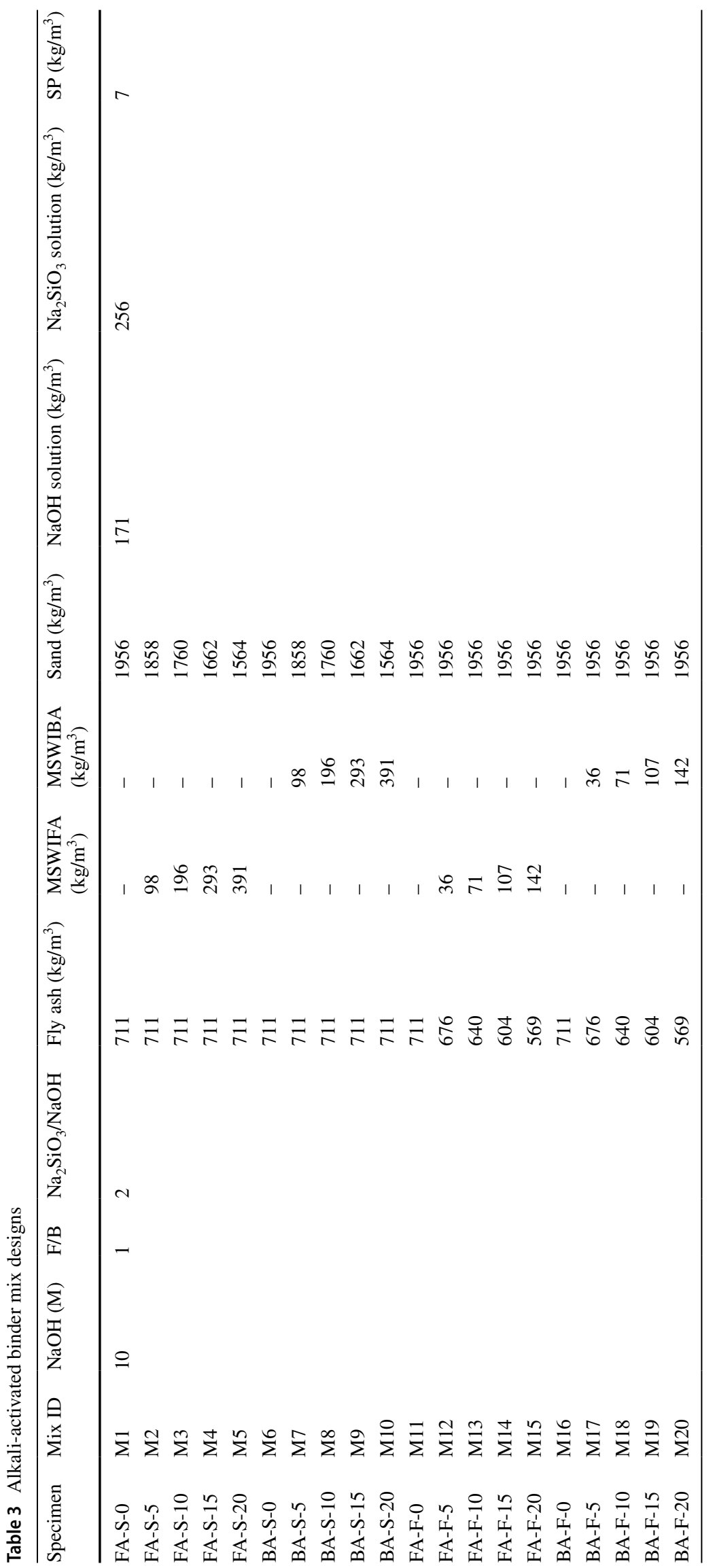


the thermal conductivity data. The size of specimens was $40 \mathrm{~mm} \times 40 \mathrm{~mm} \times 80 \mathrm{~mm}$, which was sufficient to cover the full area of the sensor. The humidity condition was measured and reported to be $55 \% \mathrm{RH}$ during the thermal conductivity test.

\section{Water absorption}

Water absorption of alkali-activated binder specimens was measured according to the ASTM C1403. Three $50 \mathrm{~mm}$ cubes for each mix design were placed in an oven for $24 \mathrm{~h}$ at $110^{\circ} \mathrm{C}$. The specimens were removed from the oven and cool in an ambient temperature for $2 \mathrm{~h}$. The dry weight was recorded for all the specimens, and then the binder specimens were placed in a container. The specimens were partially immersed in water with depth of $3 \pm 0.5 \mathrm{~mm}$. The binder specimens' weight were recorded at $0.25 \mathrm{~h}, 1 \mathrm{~h}, 4 \mathrm{~h}$ and $24 \mathrm{~h}$. After that, the weight was recorded on a daily basis until there were no difference between the two successive weightings.

\section{Thermal stability}

Thermogravimetric analysis (TGA) test was performed to investigate the effect of MSWI ashes on thermal stability of alkali-activated binder. Fragments extracted from selected specimens were first grinded to a size of $45 \mu \mathrm{m}$ then tested using Thermogravimetric Analyzer TGA 4000 PerkinElmer device in the range of $30{ }^{\circ} \mathrm{C}$ and $730{ }^{\circ} \mathrm{C}$. The mass loss in the specimens was monitor with respect to the temperature.

\section{Chemical composition analysis}

The effect of MSWI ashes on the chemical composition of the produced binder was examined using X-ray fluorescence (XRF) technique. Small pieces were taken out from different

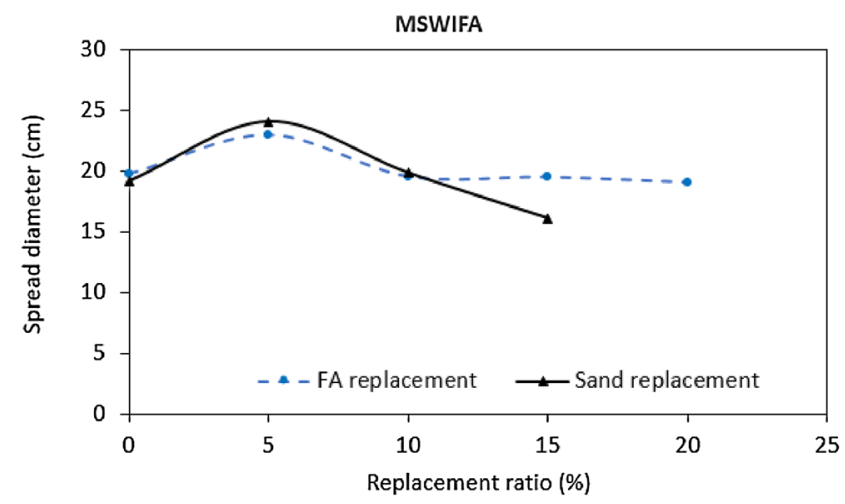

(a) location of the compression specimens, grinded to powder that pass sieve with $150 \mu \mathrm{m}$ opening, and tested using JSX $3201 \mathrm{M}$ (Jeol) spectroscopy device.

\section{Heavy metals concentrations}

The total concentration of the heavy metals in the MSWI ashes and binder specimens was measured by inductively coupled plasma-Optical Emission (ICP-OES). Acid digestion followed by ICP-OES were used for samples elemental analysis. The digestion was optimized using $0.26 \mathrm{~g}$ of sample, $6 \mathrm{ml}$ of $\mathrm{HCl}, 2 \mathrm{ml}$ of $\mathrm{HNO}_{3}$, and $2 \mathrm{ml}$ of $\mathrm{HF}$ using microwave digestion system (MARS 6). ICP-OES was then conducted for elemental analysis using Optima 7300 DV (PerkinElmer).

\section{Experimental results and discussion}

\section{Workability}

Effect of MSWI ashes on the workability of alkali-activated binder was examined using flow table test. The spread diameter values of different binder mixes are plotted in Fig. 3. The effect of MSWIFA on the workability of the binder was more pronounced in the case of using it as sand replacement than fly ash replacement, as shown in Fig. 3a. For fly ash replacement approach, using 5\% replacement ratio increased the workability of the binder by $17 \%$. Any further replacement of the fly ash with MSWIFA up to $20 \%$ reduced the workability of the binder to be close to the control mix. In the case of sand replacement approach, using 5\% replacement ratio increased the workability of the binder by $22 \%$. Binder with $10 \%$ MSWIFA as sand replacement owned similar workability of the control mix. Increase the replacement ratio to be $15 \%$ clearly reduced the workability by $18 \%$

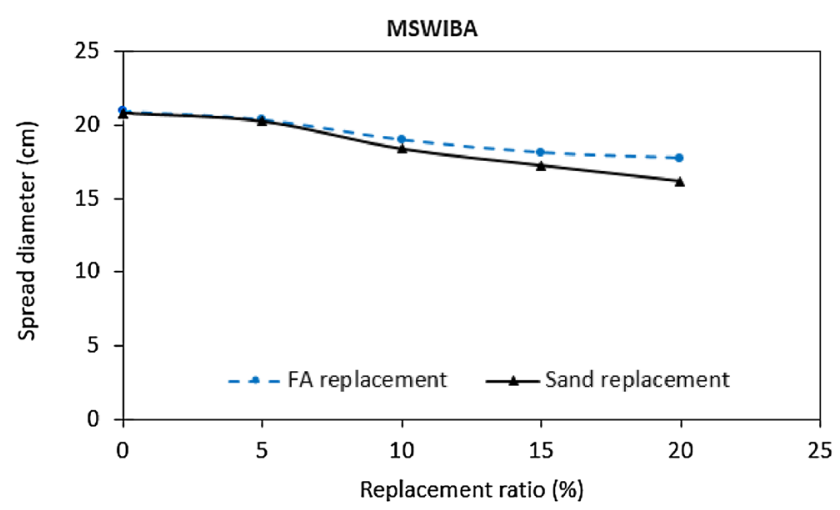

(b)

Fig. 3 Flow table results of alkali-activated binder with MSWI ashes 
compared to the control specimen. It is good to mention that specimen with $20 \%$ sand replacement ratio showed flash setting during mixing process, thus the spread diameter could not be measured.

The effect of MSWIBA on the workability of the binder is shown in Fig. 3b. It is clear in the figure that both approaches; sand and fly ash replacement; showed similar effect on the workability of the binder. Replacement 5\% of either fly ash or sand content by MSWIBA marginally increased the workability of the control mix by $3 \%$. After that, the workability of the binder decreased by $10 \%$ and $18 \%$ with increasing the MSWIBA content to be $20 \%$ for fly ash replacement and sand replacement approaches, respectively. This reduction might be ascribed to (1) the high water adsorption of the MSWI ashes [22]. The water absorption of the fly ash, MSWIFA, and MSWIBA used in this study was equal to $1.15 \%, 5 \%$, and $4 \%$, respectively. Or (2) the irregular shape and rough surface of the MSWI ashes [23, 24].

\section{Density}

Figure 4 shows the density of the alkali-activated binder with different dosages of MSWI ashes as either fly ash or sand replacement. It was noted that incorporating the ashes in the binder insignificantly affected its density. The density of the control specimen was equal to $1.92 \mathrm{~g} / \mathrm{cm}^{3}$. The density of specimens with different dosages of either MSWIFA or MSWIBA located within $5 \%$ of the control specimen. The slight reduction in the density due to the incorporation of the MSWI ashes could be attributed to the lighter specific gravity and porous nature of the ashes [22].

\section{Mechanical strengths}

Effect of incorporating MSWI ashes as either fly ash replacement or sand replacement on the mechanical strengths of alkali-activated binder is discussed in this section. The strength values combined with the reduction ratios and the standard deviation values are summarized in Table 4. The compressive strength of alkali-activated binder without MSWI ashes (control specimen) equals to $40.93 \mathrm{MPa}$. Replacement up to $10 \%$ of the fly ash content with MSWIFA marginally reduced the compressive strength of the binder by $5 \%$. Any more replacement of the fly ash with MSWIFA caused clear reduction in the compressive strength, the reduction reached up to $46 \%$ compared to the control specimen in the case of $20 \%$ replacement ratio. Similar results were reported in the literature $[4,5]$. On the other hand, replacement $5 \%$ of the fly ash content with MSWIBA marginally reduced the compressive strength of the binder by $3 \%$. Any more replacement caused clear reduction in the compressive strength. The reduction reached up to $35 \%$ compared to the control specimen in the case of

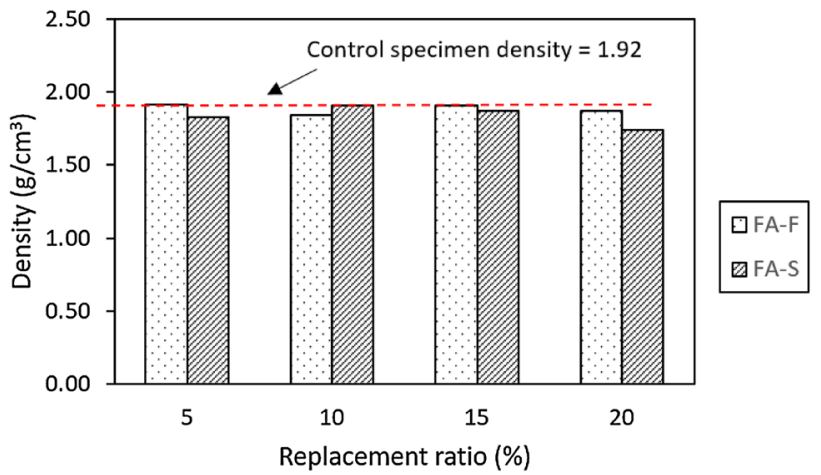

(a)

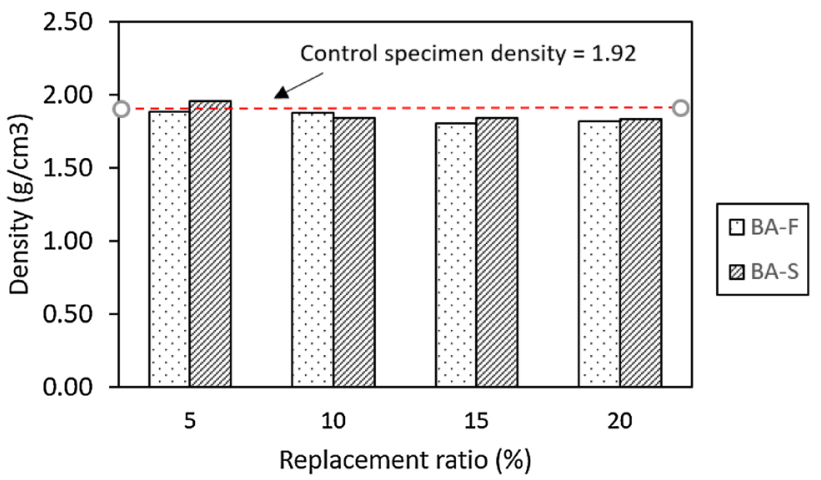

(b)

Fig. 4 Density of alkali-activated binder with different dosages of MSWI a FA, b BA as either fly ash or sand replacement

$20 \%$ replacement ratio. The reduction in the mechanical strengths of alkali-activated binder due to fly ash replacement with MSWI ashes could be attributed to the different mineral compositions between the fly ash and the incineration ashes, as shown in Table 1. Compared to fly ash, MSWIFA and MSWIBA contain very less amount of $\mathrm{SiO}_{2}$ and $\mathrm{Al}_{2} \mathrm{O}_{3}$, which contribute to the mechanical strengths of the alkali-activated binder $[5,17,25]$. The low reactivity of the MSWI ashes compared to the fly ash could be another reason beyond the reduction in the compressive strength of the binder specially for high replacement ratio [4]. Figure 5a shows that for fly ash replacement, using MSWIFA is better than MSWIBA. On contrary, for sand replacement, it is better to use the MSWIBA than the MSWIFA especially for replacement ratio more than $10 \%$, as shown in Fig. $5 \mathrm{~b}$. However, for small replacement ratio (5\%), both ashes showed neglected reduction in the compressive strength of the binder, as shown in Table 4. In addition, the results show that it is better to use the MSWIFA as fly ash replacement rather than sand replacement (Fig. 5c), whereas it is better to use the MSWIBA as sand replacement rather than fly ash replacement, as shown in Fig. 5d. These results could be attributed to the fact that the size of the MSWIBA particles is closer to the size of the sand particles, whereas the size of 
Table 4 Mechanical strengths results

\begin{tabular}{lllllll}
\hline Sample ID & $\begin{array}{l}\text { Compressive } \\
\text { strength (MPa) }\end{array}$ & Std & Reduction (\%) & $\begin{array}{l}\text { Flexural } \\
\text { strength (MPa) }\end{array}$ & Std & Reduction (\%) \\
\hline Control & 40.93 & 0.71 & & 0.59 & 0.01 & \\
FA-F-5 & 40.68 & 0.06 & 1 & 0.55 & 0.01 & 8 \\
FA-F-10 & 38.90 & 0.06 & 5 & 0.44 & 0.01 & 26 \\
FA-F-15 & 27.70 & 1.09 & 32 & 0.34 & 0.02 & 42 \\
FA-F-20 & 22.24 & 0.31 & 46 & 0.24 & 0.00 & 59 \\
Control & 40.93 & 0.71 & & 0.59 & 0.01 & \\
BA-F-5 & 39.54 & 0.36 & 3 & 0.55 & 0.02 & 7 \\
BA-F-10 & 32.79 & 0.13 & 20 & 0.48 & 0.04 & 19 \\
BA-F-15 & 27.13 & 0.76 & 34 & 0.28 & 0.02 & 53 \\
BA-F-20 & 26.57 & 0.32 & 35 & 0.29 & 0.03 & 52 \\
Control & 40.93 & 0.71 & & 0.59 & 0.01 & \\
FA-S-5 & 41.30 & 0.49 & -1 & 0.38 & 0.01 & 36 \\
FA-S-10 & 28.71 & 0.48 & 30 & 0.36 & 0.01 & 39 \\
FA-S-15 & 21.09 & 0.17 & 48 & 0.30 & 0.03 & 50 \\
FA-S-20 & 7.79 & 0.23 & 81 & 0.14 & 0.03 & 76 \\
Control & 40.93 & 0.71 & & 0.59 & 0.01 & \\
BA-S-5 & 39.81 & 1.26 & 3 & 0.59 & 0.05 & 0 \\
BA-S-10 & 35.03 & 1.49 & 14 & 0.53 & 0.01 & 10 \\
BA-S-15 & 33.34 & 0.52 & 19 & 0.39 & 0.02 & 35 \\
BA-S-20 & 30.59 & 1.35 & 25 & 0.39 & 0.03 & 35 \\
\hline
\end{tabular}

the MSWIFA particles is closer to the fly ash particles [26], as shown in Fig. 1. When the gradation is appropriate, the cemented materials has relatively dense microstructure and superior structural performance $[27,28]$. In addition, the size of the particles involved in the mix has a great effect on the strength of the cementitious binders, where the size of the sand particles affects the number and the size of the voids through the matrix as reported in many literatures [23, 29].

The flexural strength of alkali-activated binder without MSWI ashes (control specimen) equals to $0.59 \mathrm{MPa}$. The results show that using small dosages $(5 \%)$ of either MSWIFA or MSWIBA as fly ash replacement caused marginal reduction to the flexural strength of the binder by $8 \%$ and 7\%, respectively, as shown in Fig. 6a. The reduction increased with increasing the dosages of the MSWIFA and MSWIBA to reach up to 52\% and 59\% of the flexural strength of the control specimens for replacement ratio of $20 \%$, as cleared in Table 4 . For sand replacement approach, using 5\% of MSWIBA did not affect the flexural strength of the binder, as shown in Fig. 6b. Increasing the dosage to be $10 \%$ reduced the strength by $10 \%$. Further increase in the MSWIBA content caused clear reduction in the flexural strength to be $35 \%$ in the case of $20 \%$ replacement ratio. On contrary, MSWIFA is not good to be used as sand replacement, since using small dosages (5\%) caused significant reduction in the flexural strength of the binder by $36 \%$, as shown in Table 4.

\section{Thermal insulation capacity}

Effect of MSWI ashes on the thermal insulation capacity of alkali-activated binder was investigated using thermal conductivity test. The results are presented in Fig. 7. It is clear that sand or fly ash replacement with small dosages of MSWIFA (up to 10\%) slightly affected the thermal insulation capacity of the binder. No changes in the thermal conductivity were monitored in the case of fly ash replacement, whereas insignificant increase by $6 \%$ and $4 \%$, where noticed in the case of $5 \%$ and $10 \%$ sand replacement, respectively. For high replacement ratio, significant reduction in the conductivity was noticed especially for sand replacement. Maximum reduction was equal to $21 \%$ in the case of $15 \%$ sand replacement. On contrary, clear enhancement in the thermal insulation capacity of the alkali-activated binder was noticed in the case of MSWIBA incorporation as either fly ash or sand replacement. Figure $7 \mathrm{~b}$ shows that presence of MSWIBA reduced the thermal conductivity of the binder for all replacement ratios and for both fly ash and sand replacement. The reduction in the conductivity values in the case of fly ash and sand replacement started at $17 \%$ and $14 \%$, respectively, for $5 \%$ replacement ratio and increased up to $34 \%$ and $29 \%$ in the case of $20 \%$ replacement ratio. Similar results reported in the literature $[30,31]$. It was also noted that specimens with MSWIBA owned lower thermal conductivity than those with MSWIFA. This could 


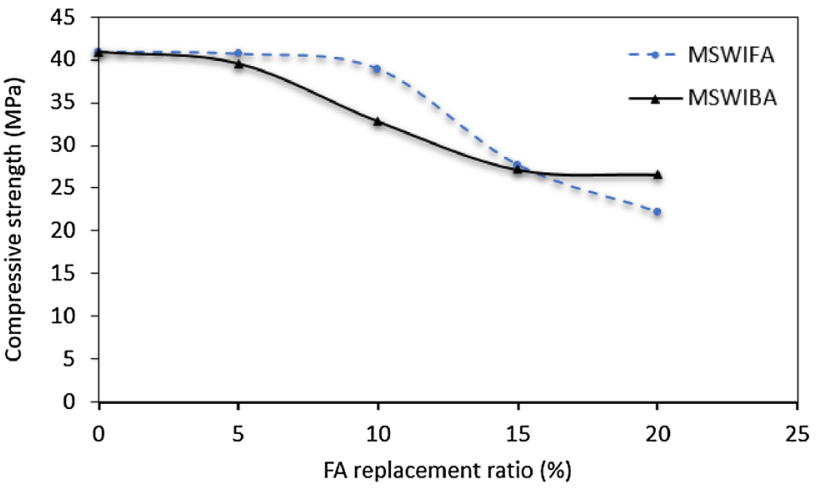

(a)

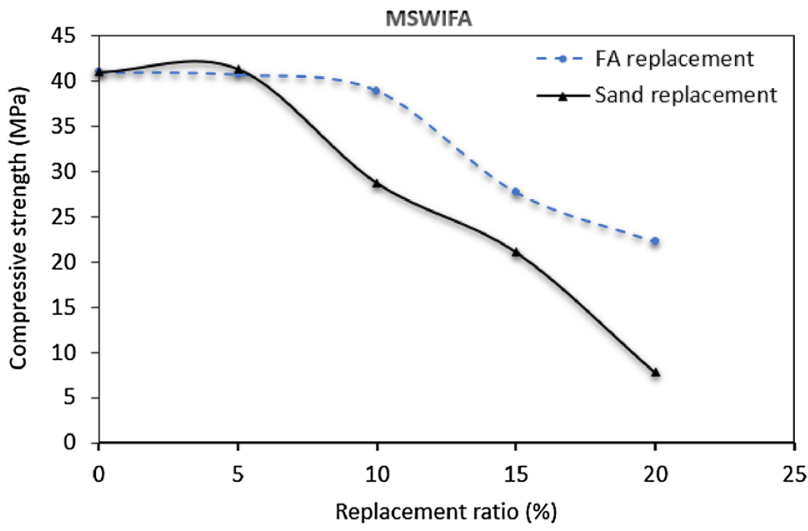

(c)

Fig. 5 Compressive strength of alkali-activated binder with MSWI ashes

be attributed to the high porosity and low density of the BA compared to the FA [32].

\section{Water absorption}

Effect of MSWI ashes on the water absorption capability of the alkali-activated binder was investigated, and the results are presented in Fig. 8. It was noted that the presence of MSWI ashes in the binder increased its water absorption capability. This result attributed to the higher water absorption of the MSWI ashes compared to both fly ash and sand [23]. For both approaches (fly ash and sand replacement), the increase in the water absorption was clear in the specimens with MSWIFA, as shown in Fig. 8a, b, but it was insignificant in the specimens with MSWIBA, as shown in Fig. 8c, $\mathrm{d}$. In addition, the water absorption capability increased with increasing the MSWI ashes dosages. Similar results are reported in the literature [5, 33]. Specimens with MSWIFA showed higher water absorption capability than those with MSWIBA due to the facts that the MSWIFA owned smaller particle size and higher surface area than MSWIBA. Finally, it was noted that all specimens reached the plateau stage

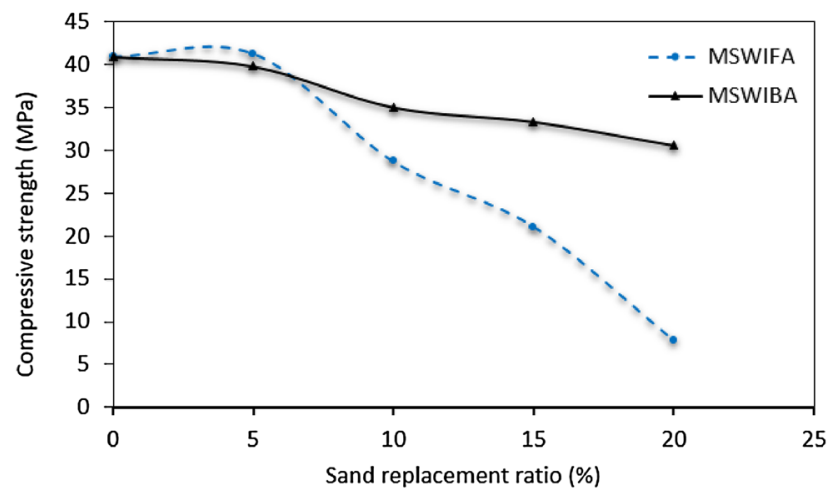

(b)

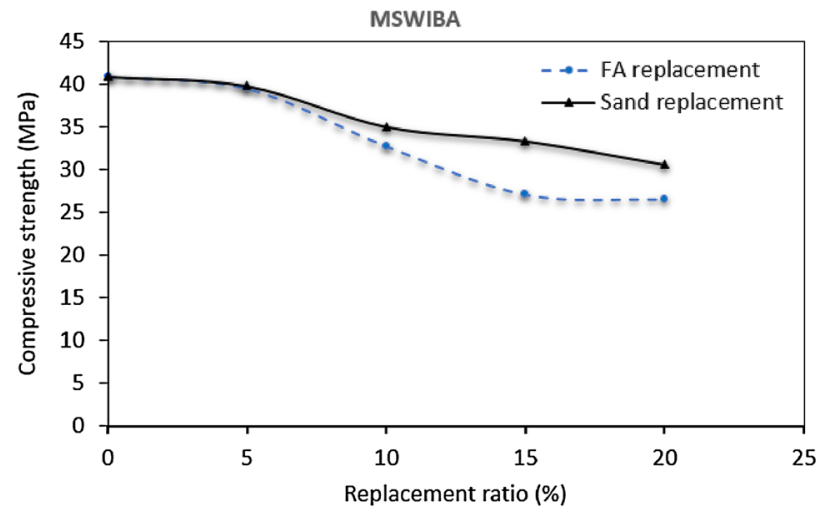

(d)

with constant absorption after $24 \mathrm{~h}$, reflected the high rate of absorption of the binder at early ages.

\section{Thermal stability}

Specimens with best mechanical strength results $(5 \%$ replacement ratio) were selected to perform the TGA test to compare the replacement approach for both MSWI ashes. Thermogravimetric (TGA) profiles and their corresponding derivative function (DTG) curves of the selected alkali-activated binder specimens are presented in Fig. 9. The figure gives an indication about the effect of adding MSWI ashes to the binder as either fly ash or sand replacement on the weight loss of the specimens when exposed to elevated temperature up to $730{ }^{\circ} \mathrm{C}$.

Figure 9 reveals that all TGA curves could be divided into four stages. Stage one (S1) was located between 0 to $120^{\circ} \mathrm{C}$. The weight loss in this stage was associated with the evaporation of the free water presented on the surface and porosity of the specimens $[34,35]$. The second stage (S2) was located between 120 to $230{ }^{\circ} \mathrm{C}$. The weight loss in this stage could be attributed to the evaporation of the chemically 


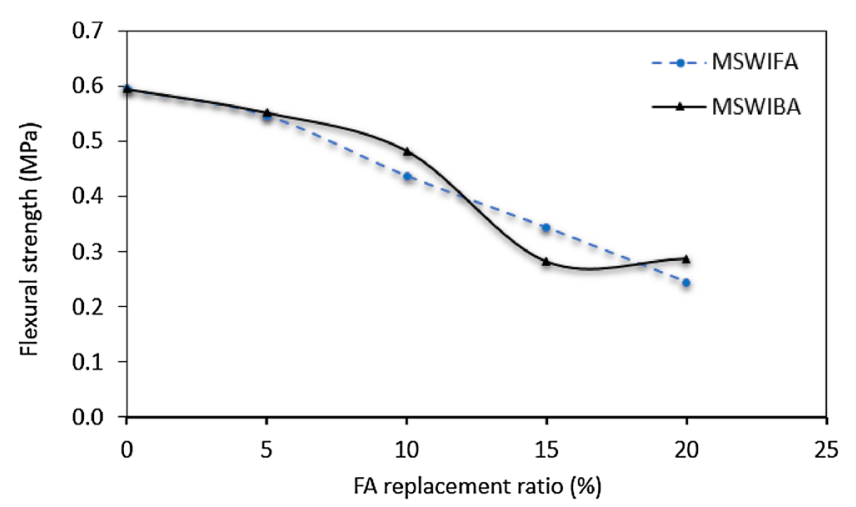

(a)

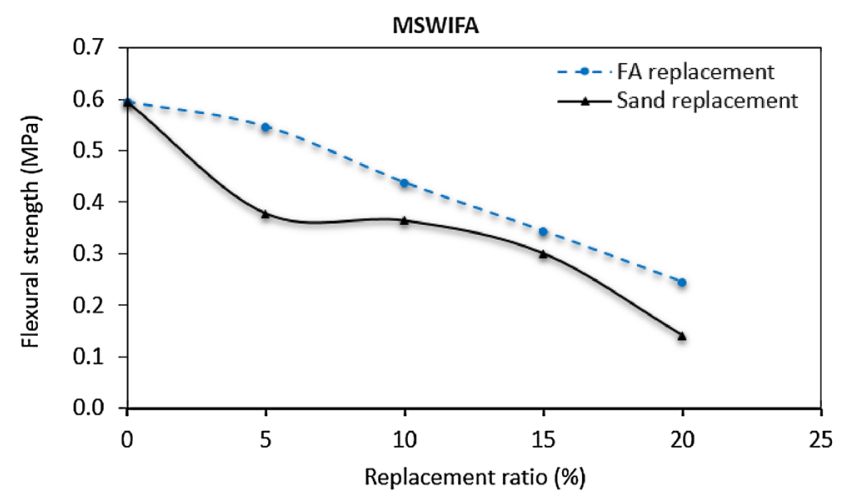

(c)

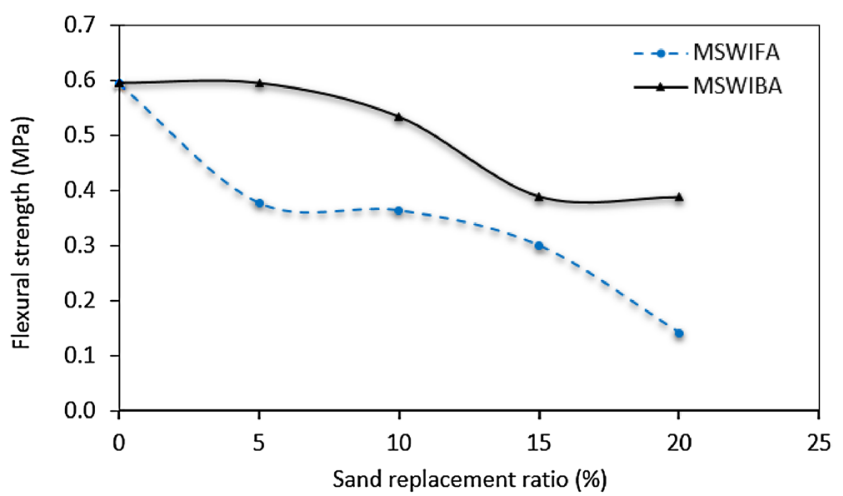

(b)

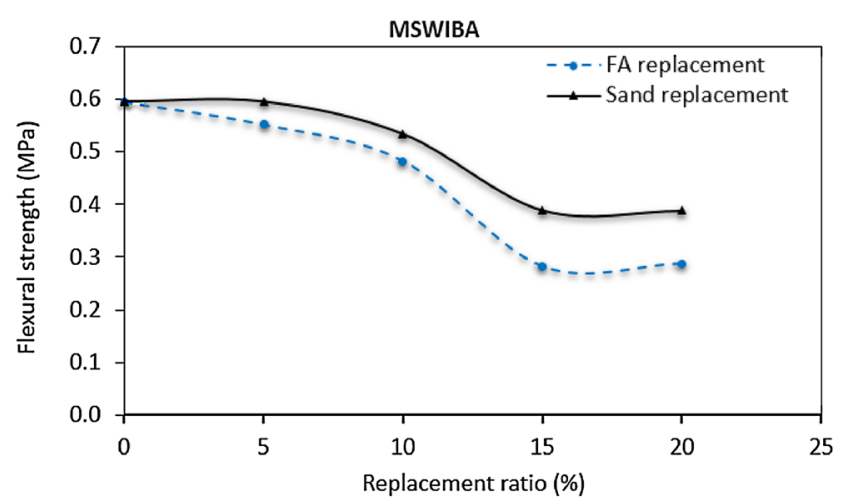

(d)

Fig. 6 Flexural strength of alkali-activated binder with MSWI ashes

bound water [34, 36], or was associated with the presence of NASH gel [37]. After the second stage, the rate of the weight loss stabilized between 230 to $630^{\circ} \mathrm{C}$ (S3). Another weight loss was captured between 630 and $730^{\circ} \mathrm{C}$ (S4). This weight loss could be attributed to the dehydroxylation and recrystallization of geopolymer specimens [35].

It is clear in Fig. 9a, b that the total weight loss of the fly ash-based geopolymers did not exceed $8 \%$, which agreed with the literatures $[38,39]$. It is also clear that the effect of the fly ash replacement on the total weight loss of the binder was more pronounced than the sand replacement for both types of the ashes, as shown in Fig. 9a, b.

In addition, the first peak in the DTG curves of alkaliactivated binder with MSWIFA got higher and wider than that of binder with MSWIBA, as shown in Fig. 9c. This result could be attributed to the following two reasons. (1) The fact that specimen with 5\% MSWIFA as sand replacement contains more calcium (Ca) atoms than specimen with 5\% MSWIBA as shown later in the XRF results; therefore, it can hold pore water more strongly [34]. Knowing that presence of $\mathrm{Ca}$ in the geopolymer gel is helpful in holding the pore water through the formation of new phases [40]. (2)
The fact that specimen with 5\% MSWIFA as sand replacement absorb more water compared to specimen with 5\% MSWIBA as shown in the previous section. Thus, evaporation of more free water from the specimen would take place, which caused more increase in the mass loss.

\section{Chemical composition and heavy metals concentrations}

XRF test was conducted to determine the chemical composition of alkali-activated binder with various dosages of MSWI ashes as either fly ash or sand replacement. The results are summarized in Table 5. It is clear in the table that the main oxides presented in the control specimens are $\mathrm{SiO}_{2}, \mathrm{CaO}, \mathrm{Al}_{2} \mathrm{O}_{3}$, and $\mathrm{Fe}_{2} \mathrm{O}_{3}$. These oxides come from the fly ash that used as source material in the binder mix design, as shown in Table 1. Clear reduction in the silica content was noted for specimens with both MSWIFA and MSWIBA. The reduction was more significant in the case of sand replacement than fly ash replacement. The reason beyond that could be attributed to high silica content in the sand used to prepare the mix (silica sand). On contrary, clear 


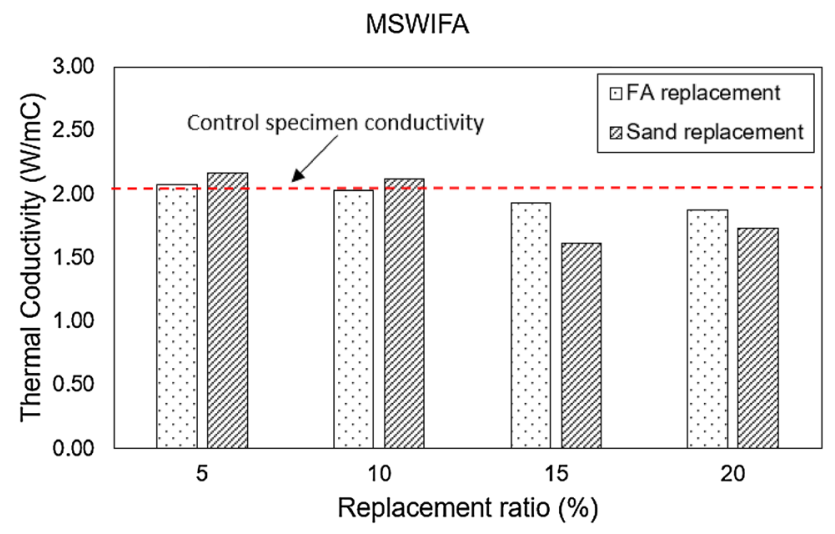

(a)

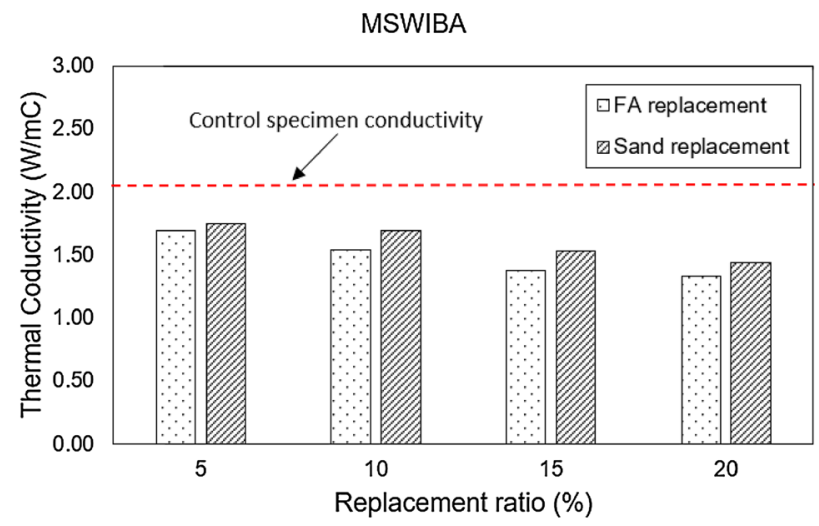

(b)

Fig. 7 Thermal conductivity of alkali-activated binder with different dosages of MSWI a FA, b BA as either fly ash or sand replacement

increase in the alumina was noted specially for sand replacement specimens, this could be due to the high content of aluminum oxides in the MSWI ashes.

Since some of the heavy metals were observed in the binder by the XRF analysis, ICP-OES analysis was carried out to investigate the total concentration of these metals in alkali-activated binder with MSWI ashes. The traced elements include $\mathrm{Cu}, \mathrm{Cr}, \mathrm{Mn}, \mathrm{Ni}, \mathrm{Zn}$, and $\mathrm{Pb}$. The results are presented in Table 6 . The concentrations of $\mathrm{Zn}, \mathrm{Mn}$, and $\mathrm{Cr}$ were the highest among all other traced metals in the binder specimens. However, their concentrations showed different tendency with the increase of MSWI ash content. With the increase of the MSWI ash replacement ratio, the concentration of $\mathrm{Cr}$ tended to decrease, whereas the concentration of $\mathrm{Zn}$ tended to increase. The variation in the heavy metals concentration within the binders may indicate to possible migration of some of these metals into the binder during the geopolymerization process. The migration of these metals depends on the replacement ratio. The literatures reported that the heavy metals either transferred from the incineration ashes into the alkali-activated binder, physically encapsulated by the binder, or chemically encapsulated by the binder through their interaction with the geopolymerization products $[5,41]$.

On the other hand, leaching of heavy metals is a major concern for any potential application of MSWI ashes in construction industry. Due to the material's potential applications, further research into the mobility of these metals through a leaching procedure is highly recommended. However, many published literatures proved the ability of the alkali-activated composites to stabilize and immobilize the heavy metals through the geopolymerization process [5, 17-19], thus reduced the leaching amount of the toxic metals to be within the limits.

\section{Recommendation and future work}

Investigating the effect of MSWI ashes on the durability of alkali-activated binders is an essential, as it affects the decision to incorporate these wastes in the construction industry. In this regards, it is recommended to investigate the effect of these ashes on dry shrinkage, sulfate acid resistance, and chloride permeability of the binders. In addition, comprehensive study should be conducted to investigate the variation in the chemical composition of the ashes with time and waste source.

\section{Conclusions}

The feasibility of using two types of municipality solid wastes incineration ashes (MSWIA), namely, fly ash and bottom in the production of sustainable alkali-activated binder was investigated in this study. The incineration ashes were incorporated in the binder mix as either fly ash or sand replacement with five replacement ratios $0 \%, 5 \%, 10 \%, 15 \%$, and $20 \%$. The produced binder were characterized in terms of mechanical strengths, workability, density, water absorption, thermal conductivity, thermal stability, chemical composition, and heavy metals content. The main conclusion of this study was that sustainable alkali-activated binder with better thermal insulation capability could be produced with small dosages (5\%) of MSWI ashes without negatively affecting the binder strengths, workability, density, and water absorption. The following detailed conclusions could be extracted from the experimental work presented in this research:

1. To produce sustainable alkali-activated binder with MSWI ashes, the incineration fly ash could be used to replace $5 \%$ of the fly ash content, whereas the incineration bottom ash could be used to replace $5 \%$ of the fly 


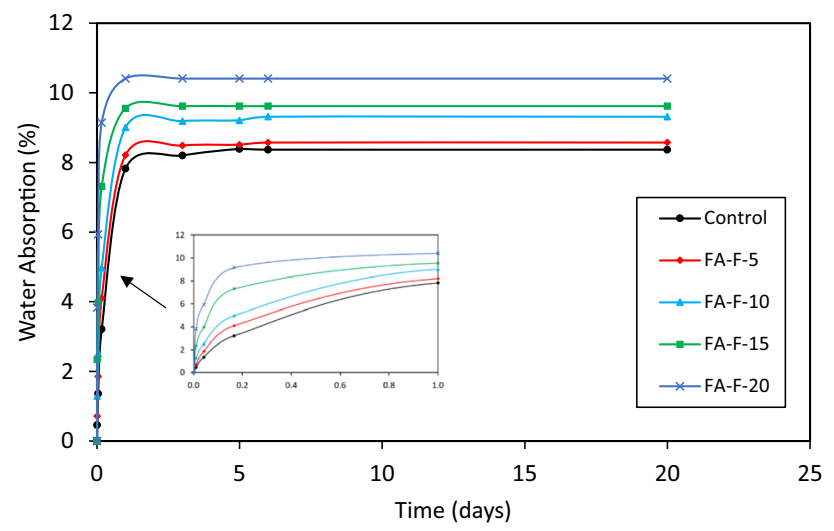

(a)

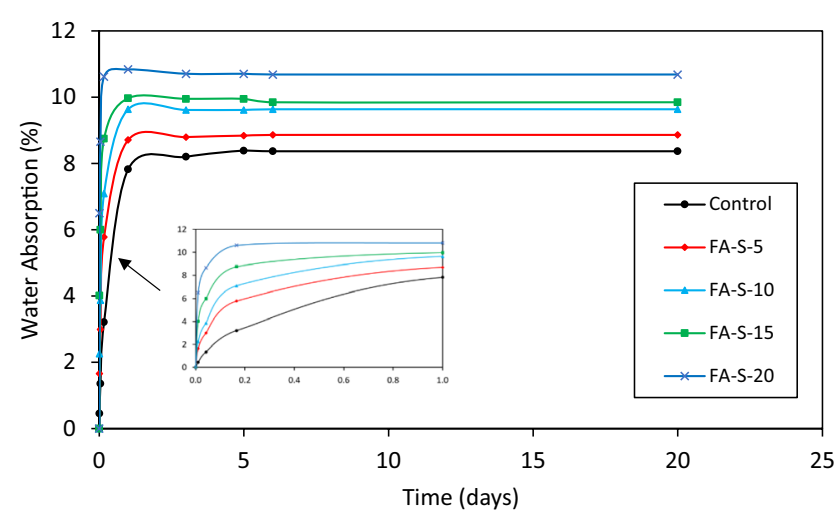

(b)

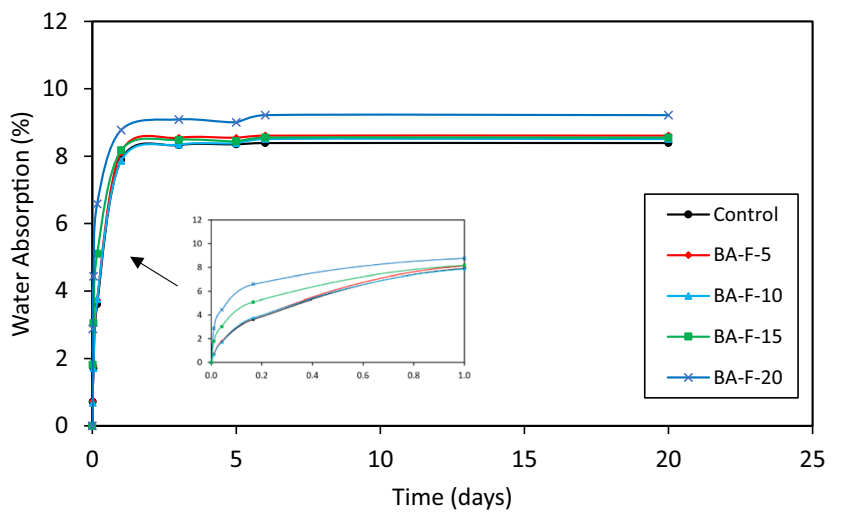

(c)

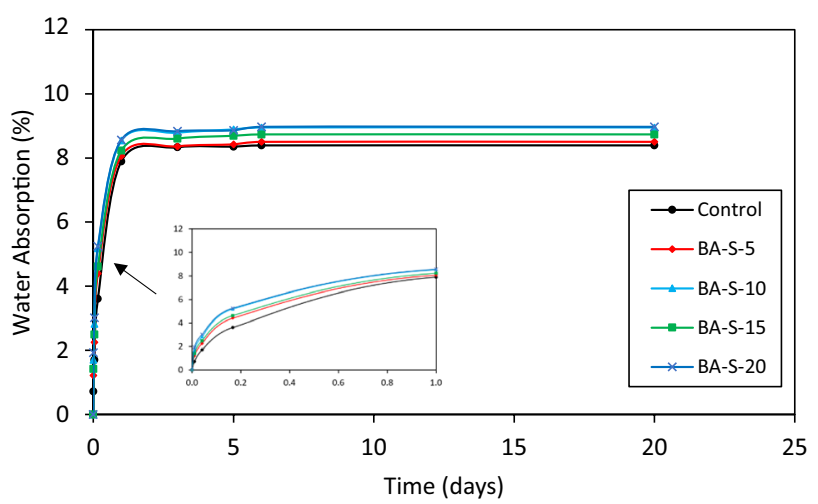

(d)

Fig. 8 Water absorption of alkali-activated binder with MSWIFA a FA replacement, b sand replacement and MSWIBA, c FA replacement, d sand replacement

ash content or $10 \%$ of the sand content without negative effect on the mechanical strengths of the binder.

2. Small dosages of MSWI ashes (up to 10\%) slightly affected the workability of the alkali-activated binder, whereas high dosages clearly reduced the workability. The reduction was more pronounced in the case of MSWIBA.

3. Incorporating MSWI ashes as either fly ash or sand replacement insignificantly affected the density of the alkali-activated binder.

4. MSWI ashes enhanced the thermal insulation properties of the alkali-activated binder. The presence of MSWIBA reduced the thermal conductivity of the binder for all studied replacement ratios and for both fly ash and sand replacement. Small dosages of MSWIFA slightly affect the conductivity, whereas large dosages clearly enhanced it.

5. Presence of MSWI ashes in the alkali-activated binder increased its water absorption capability. The water absorption capability increased with increasing the MSWI ashes dosages. Specimens with MSWIFA showed higher water absorption capability than those with MSWIBA

6. The heavy metals presented in the MSWI ashes migrated into the alkali-activated binder. The migration of these metals depends on the replacement ratio. Investigating the mobility of these metals through a leaching procedure is highly recommended before any potential application of the incineration ashes in the construction industry. 
Fig. 9 TGA and DTG curves for alkali-activated binder with 5\% MSWI ashes as sand or fly ash replacement

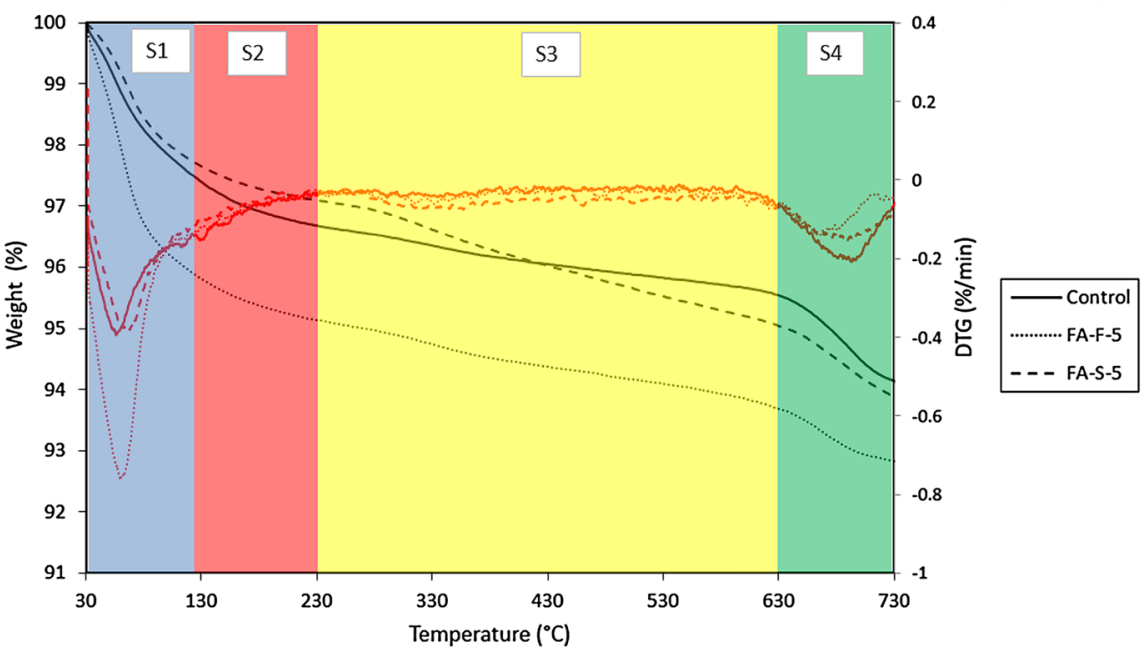

(a)

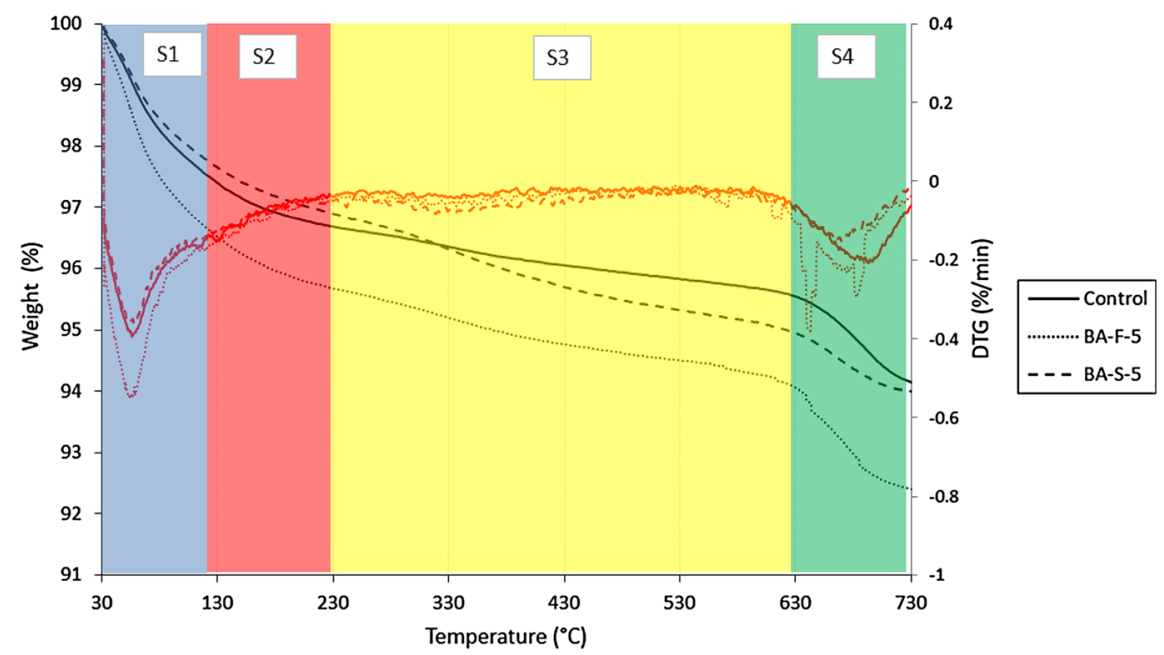

(b)

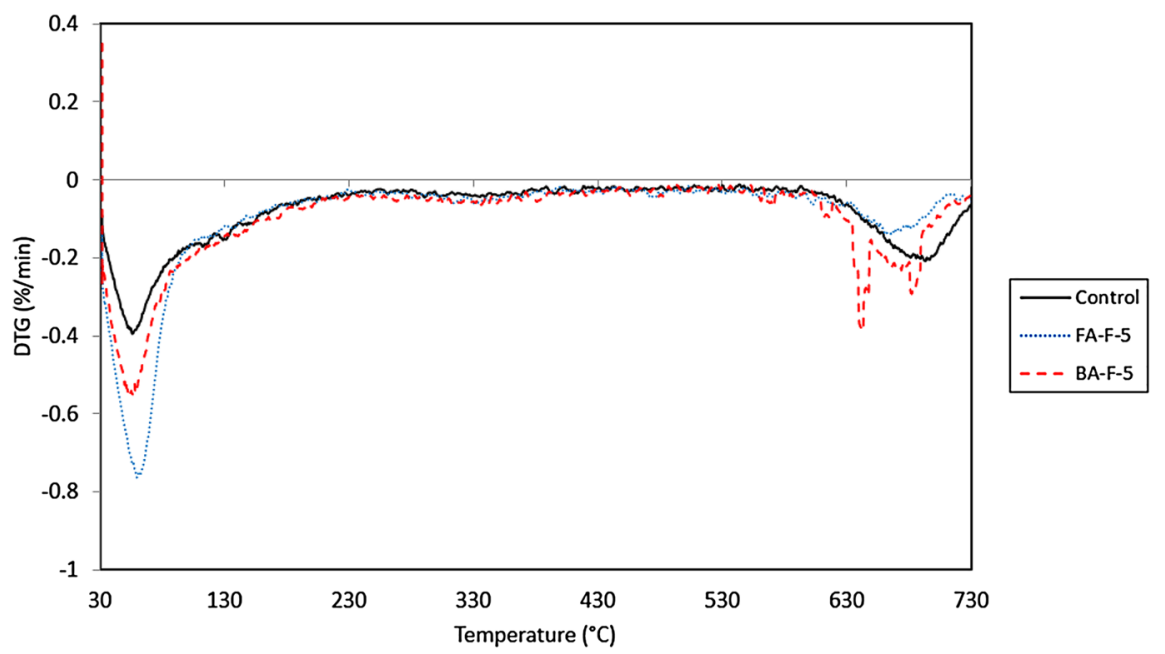

(c) 


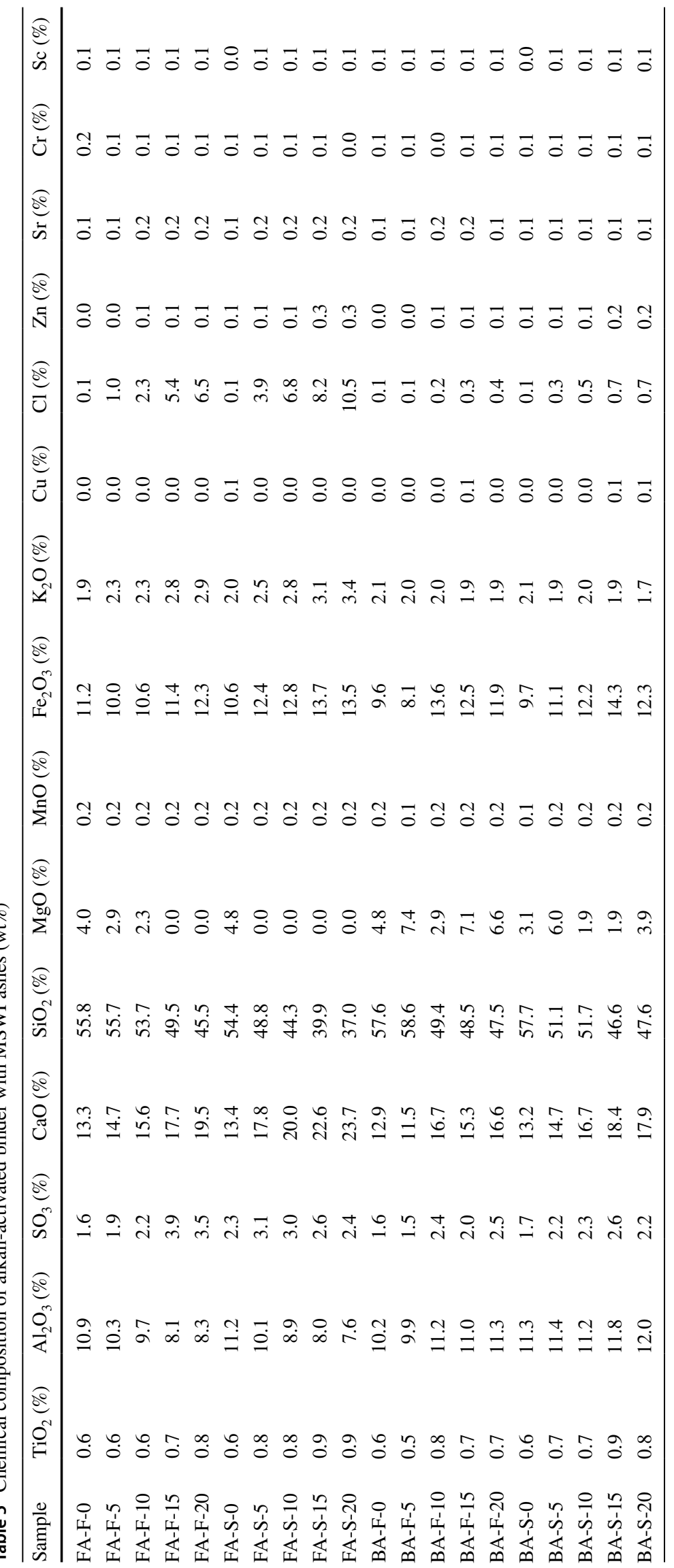


Table 6 Heavy metal concentrations in alkaliactivated binder with MSWI ashes

\begin{tabular}{|c|c|c|c|c|c|c|}
\hline \multirow[t]{2}{*}{ Sample } & \multicolumn{6}{|c|}{ Total concentration $(\mathrm{mg} / \mathrm{kg})$} \\
\hline & $\mathrm{Cu}$ & $\mathrm{Cr}$ & $\mathrm{Mn}$ & $\mathrm{Ni}$ & $\mathrm{Zn}$ & $\mathrm{Pb}$ \\
\hline FA-F-0 & 14.79 & 234.7 & 252.6 & 13.05 & 54.61 & 15.73 \\
\hline FA-F-5 & 16.34 & 134.2 & 225.5 & 9.916 & 128.7 & 22.51 \\
\hline FA-F-10 & 21.32 & 108.5 & 236.1 & 10.38 & 208.6 & 32.56 \\
\hline FA-F-15 & 22.44 & 110.5 & 212.3 & 8.404 & 269.6 & 36.82 \\
\hline FA-F-20 & 26.62 & 76.31 & 206.8 & 8.194 & 373.5 & 45.24 \\
\hline FA-S-0 & 12.45 & 164.7 & 195.1 & 9.526 & 54.61 & 4.595 \\
\hline FA-S-5 & 24.06 & 91.12 & 230 & 9.937 & 128.7 & 29.25 \\
\hline FA-S-10 & 35.39 & 94.96 & 225.8 & 10.26 & 208.6 & 51.84 \\
\hline FA-S-15 & 28.52 & 51.85 & 146.8 & 6.454 & 269.6 & 49.13 \\
\hline FA-S-20 & 53.4 & 61.00 & 227.6 & 11.93 & 373.5 & 95.38 \\
\hline BA-F-0 & 25.2 & 163.6 & 244.6 & 10.75 & 93.48 & 17.7 \\
\hline BA-F-5 & 26.49 & 176.4 & 219.5 & 9.657 & 98.19 & 21.04 \\
\hline BA-F-10 & 126.4 & 47.1 & 267.2 & 12.78 & 209.4 & 33.8 \\
\hline BA-F-15 & 62.82 & 81.23 & 244.3 & 13.27 & 227.3 & 36.9 \\
\hline BA-F-20 & 102.4 & 59.67 & 252.9 & 13.24 & 340.2 & 47.2 \\
\hline BA-S-0 & 11.89 & 138.9 & 173.5 & 8.125 & 93.48 & 7.013 \\
\hline BA-S-5 & 51.43 & 102.4 & 190.8 & 14.94 & 98.19 & 21.61 \\
\hline BA-S-10 & 105.7 & 125.5 & 208.9 & 12.18 & 209.4 & 46.28 \\
\hline BA-S-15 & 101.9 & 78.79 & 199.1 & 10.23 & 227.3 & 53.59 \\
\hline BA-S-20 & 156.3 & 123.2 & 242.0 & 19.82 & 340.2 & 92.63 \\
\hline
\end{tabular}

Acknowledgements The ICP-OES analysis of alkali-activated binder specimens was accomplished in the Central Laboratories Unit, Qatar University.

Funding Open Access funding provided by the Qatar National Library.

Data availability Data available on request from the authors.

\section{Declarations}

Conflict of interest The authors reported no potential conflict of interest.

Open Access This article is licensed under a Creative Commons Attribution 4.0 International License, which permits use, sharing, adaptation, distribution and reproduction in any medium or format, as long as you give appropriate credit to the original author(s) and the source, provide a link to the Creative Commons licence, and indicate if changes were made. The images or other third party material in this article are included in the article's Creative Commons licence, unless indicated otherwise in a credit line to the material. If material is not included in the article's Creative Commons licence and your intended use is not permitted by statutory regulation or exceeds the permitted use, you will need to obtain permission directly from the copyright holder. To view a copy of this licence, visit http://creativecommons.org/licenses/by/4.0/.

\section{References}

1. da Silva LJVB, dos Santos IFS, Mensah JHR, Gonçalves ATT, Barros RM (2020), Incineration of municipal solid waste in Brazil: an analysis of the economically viable energy potential.
Renew Energy 149:1386-1394. https://doi.org/10.1016/j.renene. 2019.10.134

2. Mukherjee C, Denney J, Mbonimpa EG, Slagley J, Bhowmik R (2020) A review on municipal solid waste-to-energy trends in the USA. Renew Sustain Energy Rev 119:109512. https://doi.org/10. 1016/j.rser.2019.109512

3. Tang Z, Li W, Tam VWY, Xue C (2020) Advanced progress in recycling municipal and construction solid wastes for manufacturing sustainable construction materials. Resour Conserv Recycl X 6:100036. https://doi.org/10.1016/j.rcrx.2020.100036

4. Kan L, Shi R, Zhao Y, Duan X, Wu M (2020) Feasibility study on using incineration fly ash from municipal solid waste to develop high ductile alkali-activated composites. J Clean Prod 254:120168. https://doi.org/10.1016/j.jclepro.2020.120168

5. Liu J, Hu L, Tang L, Ren J (2021) Utilisation of municipal solid waste incinerator (MSWI) fly ash with metakaolin for preparation of alkali-activated cementitious material. J Hazard Mater 402:123451. https://doi.org/10.1016/j.jhazmat.2020.123451

6. Silva RV, de Brito J, Lynn CJ, Dhir RK (2019) Environmental impacts of the use of bottom ashes from municipal solid waste incineration: a review. Resour Conserv Recycl 140:23-35. https:// doi.org/10.1016/j.resconrec.2018.09.011

7. Lei Y, Wei L, Liu T, Xiao Y, Dang Y, Sun D, Holmes DE (2018) Magnetite enhances anaerobic digestion and methanogenesis of fresh leachate from a municipal solid waste incineration plant. Chem Eng J 348:992-999. https://doi.org/10.1016/j.cej.2018.05. 060

8. Quina MJ, Bontempi E, Bogush A, Schlumberger S, Weibel G, Braga R, Funari V, Hyks J, Rasmussen E, Lederer J (2018) Technologies for the management of MSW incineration ashes from gas cleaning: new perspectives on recovery of secondary raw materials and circular economy. Sci Total Environ 635:526-542. https:// doi.org/10.1016/j.scitotenv.2018.04.150 
9. Ma W, Chen D, Pan M, Gu T, Zhong L, Chen G, Yan B, Cheng Z (2019) Performance of chemical chelating agent stabilization and cement solidification on heavy metals in MSWI fly ash: a comparative study. J Environ Manag 247:169-177. https://doi. org/10.1016/j.jenvman.2019.06.089

10. Wang J, Xie J, Wang C, Zhao J, Liu F, Fang C (2020) Study on the optimum initial curing condition for fly ash and GGBS based geopolymer recycled aggregate concrete. Constr Build Mater 247:118540. https://doi.org/10.1016/j.conbuildmat.2020.118540

11. Lancellotti I, Ponzoni C, Barbieri L, Leonelli C (2013) Alkali activation processes for incinerator residues management. Waste Manag 33:1740-1749. https://doi.org/10.1016/j.wasman.2013.04. 013

12. Zhu W, Chen X, Struble LJ, Yang E-H (2019) Quantitative characterization of aluminosilicate gels in alkali-activated incineration bottom ash through sequential chemical extractions and deconvoluted nuclear magnetic resonance spectra. Cement Concr Compos 99:175-180. https://doi.org/10.1016/j.cemconcomp.2019.03.014

13. Ivan Diaz-Loya E, Allouche EN, Eklund S, Joshi AR, KupwadePatil K (2012) Toxicity mitigation and solidification of municipal solid waste incinerator fly ash using alkaline activated coal ash. Waste Manag 32:1521-1527. https://doi.org/10.1016/j.wasman. 2012.03.030

14. Ye N, Chen Y, Yang J, Liang S, Hu Y, Xiao B, Huang Q, Shi Y, Hu J, Wu X (2016) Co-disposal of MSWI fly ash and Bayer red mud using an one-part geopolymeric system. J Hazard Mater 318:70-78. https://doi.org/10.1016/j.jhazmat.2016.06.042

15. Zhao S, Muhammad F, Yu L, Xia M, Huang X, Jiao B, Lu N, Li D (2019) Solidification/stabilization of municipal solid waste incineration fly ash using uncalcined coal gangue-based alkali-activated cementitious materials. Environ Sci Pollut Res 26:25609-25620. https://doi.org/10.1007/s11356-019-05832-5

16. Zheng L, Wang W, Gao X (2016) Solidification and immobilization of MSWI fly ash through aluminate geopolymerization: based on partial charge model analysis. Waste Manag 58:270-279. https://doi.org/10.1016/j.wasman.2016.08.019

17. Wongsa A, Boonserm K, Waisurasingha C, Sata V, Chindaprasirt P (2017) Use of municipal solid waste incinerator (MSWI) bottom ash in high calcium fly ash geopolymer matrix. J Clean Prod 148:49-59. https://doi.org/10.1016/j.jclepro.2017.01.147

18. Ren J, Hu L, Dong Z, Tang L, Xing F, Liu J (2021) Effect of silica fume on the mechanical property and hydration characteristic of alkali-activated municipal solid waste incinerator (MSWI) fly ash. J Clean Prod. https://doi.org/10.1016/j.jclepro.2021.126317

19. Huang G, Yang K, Sun Y, Lu Z, Zhang X, Zuo L, Feng Y, Qian R, Qi Y, Ji Y, Xu Z (2020) Influence of $\mathrm{NaOH}$ content on the alkali conversion mechanism in MSWI bottom ash alkali-activated mortars. Constr Build Mater 248:118582. https://doi.org/10.1016/j. conbuildmat.2020.118582

20. Funari V, Braga R, Bokhari SNH, Dinelli E, Meisel T (2015) Solid residues from Italian municipal solid waste incinerators: a source for "critical" raw materials. Waste Manag 45:206-216

21. Marieta C, Guerrero A, Leon I (2021) Municipal solid waste incineration fly ash to produce eco-friendly binders for sustainable building construction. Waste Manag 120:114-124

22. Caprai V, Lazaro A, Brouwers HJH (2019) Waterglass impregnation of municipal solid waste incineration bottom ash applied as sand replacement in mortars. Waste Manag 86:87-96. https://doi. org/10.1016/j.wasman.2019.01.025

23. Mermerdaş K, Manguri S, Nassani DE, Oleiwi SM (2017) Effect of aggregate properties on the mechanical and absorption characteristics of geopolymer mortar. Eng Sci Technol Int J 20:16421652. https://doi.org/10.1016/j.jestch.2017.11.009

24. Muthusamy K, Rasid MH, Jokhio GA, Mokhtar Albshir Budiea A, Hussin MW, Mirza J (2020) Coal bottom ash as sand replacement in concrete: a review. Constr Build Mater 236:117507. https://doi. org/10.1016/j.conbuildmat.2019.117507

25. Carvalho R, Silva RV, de Brito J, Pereira MFC (2021) Alkali activation of bottom ash from municipal solid waste incineration: optimization of $\mathrm{NaOH}-$ and $\mathrm{Na}_{2} \mathrm{SiO}_{3}$-based activators. J Clean Prod 291:125930. https://doi.org/10.1016/j.jclepro.2021.125930

26. Irshidat MR, Abdel-Jawad YA, Al-Sughayer R (2018) Feasibility of producing sustainable geopolymer composites made of locally available natural pozzolan. J Mater Cycles Waste Manag 20:17511760. https://doi.org/10.1007/s10163-018-0742-5

27. Wu J, Feng M, Mao X, Xu J, Zhang W, Ni X, Han G (2018) Particle size distribution of aggregate effects on mechanical and structural properties of cemented rockfill: experiments and modeling. Constr Build Mater 193:295-311. https://doi.org/10.1016/j. conbuildmat.2018.10.208

28. Wu J, Feng M, Xu J, Qiu P, Wang Y, Han G (2018) Particle size distribution of cemented rockfill effects on strata stability in filling mining. Minerals 8:407. https://doi.org/10.3390/min8090407

29. Guan W, Qi Q, Zhang Z, Nan S (2020) Effect of sand particle size on microstructure and mechanical properties of gypsum-cemented similar materials. Materials (Basel) 13:765. https://doi.org/10. 3390/ma13030765

30. Liu MYJ, Alengaram UJ, Jumaat MZ, Mo KH (2014) Evaluation of thermal conductivity, mechanical and transport properties of lightweight aggregate foamed geopolymer concrete. Energy Build 72:238-245. https://doi.org/10.1016/j.enbuild.2013.12.029

31. Saygilı A, Baykal G (2011) A new method for improving the thermal insulation properties of fly ash. Energy Build 43:3236-3242. https://doi.org/10.1016/j.enbuild.2011.08.024

32. Wongsa A, Zaetang Y, Sata V, Chindaprasirt P (2016) Properties of lightweight fly ash geopolymer concrete containing bottom ash as aggregates. Constr Build Mater 111:637-643. https://doi.org/ 10.1016/j.conbuildmat.2016.02.135

33. Casanova S, Silva RV, de Brito J, Pereira MFC (2021) Mortars with alkali-activated municipal solid waste incinerator bottom ash and fine recycled aggregates. J Clean Prod 289:125707. https:// doi.org/10.1016/j.jclepro.2020.125707

34. Zhang HY, Kodur V, Wu B, Cao L, Qi SL (2016) Comparative thermal and mechanical performance of geopolymers derived from metakaolin and fly ash. J Mater Civ Eng 28:04015092. https://doi.org/10.1061/(ASCE)MT.1943-5533.0001359

35. Yeddula BSR, Karthiyaini S (2020) Experimental investigations and prediction of thermal behaviour of ferrosialate-based geopolymer mortars. Arab J Sci Eng 45:3937-3958. https://doi.org/ 10.1007/s13369-019-04314-7

36. Cheng-Yong H, Yun-Ming L, Abdullah MMAB, Hussin K (2017) Thermal resistance variations of fly ash geopolymers: foaming responses. Sci Rep 7:45355. https://doi.org/10.1038/srep45355

37. Alamaral-Sanchez JL, Rosas-Casarez CA, Gomez-Soberon JM, Chinchillas-Chinchillas MJ, Acuna-Aguero OH, Corral-Higuera R, Arredondo-Rea SP (2014) Experimental study of XRD, FTIR and TGA techniques in geopolymeric materials. 25-30. https:// doi.org/10.15224/978-1-63248-006-4-65

38. Colangelo F, Cioffi R, Roviello G, Capasso I, Caputo D, Aprea P, Liguori B, Ferone C (2017) Thermal cycling stability of fly ash based geopolymer mortars. Compos B Eng 129:11-17. https://doi. org/10.1016/j.compositesb.2017.06.029

39. Sivasakthi M, Jeyalakshmi R, Rajamane NP (2021) Fly ash geopolymer mortar: impact of the substitution of river sand by copper slag as a fine aggregate on its thermal resistance properties. J Clean Prod 279:123766. https://doi.org/10.1016/j.jclepro.2020. 123766

40. Bernal SA, Rodríguez ED, Mejía de Gutiérrez R, Gordillo M, Provis JL (2011) Mechanical and thermal characterisation 
of geopolymers based on silicate-activated metakaolin/slag blends. J Mater Sci 46:5477-5486. https://doi.org/10.1007/ s10853-011-5490-z

41. Maldonado-Alameda À, Giro-Paloma J, Alfocea-Roig A, Formosa J, Chimenos JM (2020) Municipal solid waste incineration bottom ash as sole precursor in the alkali-activated binder formulation. Appl Sci 10:4129. https://doi.org/10.3390/app10124129

Publisher's Note Springer Nature remains neutral with regard to jurisdictional claims in published maps and institutional affiliations. 